\title{
SUSTAINABLE USE OF WATER RESOURCES IN POTKOZARJE REGION
}

DOI: https://doi.org/10.18509/GBP210085mt

UDC: 502.131.1:556.1.06(497.6)

\section{Tanja Mislicki-Tomić Vesna Rajčević}

Faculty of Natural Sciences and Mathematics, University of Banja Luka, Republic of Srpska, Bosnia and Herzegovina

\begin{abstract}
Potkozarje is a complex regional system in the north-west Republic of Srpska, Bosnia and Herzegovina. From the administrative and territorial aspects, it encompasses different organizational units - cities of Banja Luka, Prijedor and Gradiska and municipalities of Novi Grad, Kostajnica, Kozarska Dubica and Laktasi. This regional system covers 1848.3 $\mathrm{km} 2$ with the population of 91.097 according to the 2013 population census, which represents 7.7\% of total Republic of Srpska's population. The specificities of development processes in Potkozarje result from the impact of the neighboring centers of development.
\end{abstract}

Potkozarje is characterized by low relief plains and high relief rolling hills, with mild elevations and ununiformed terrain, which limits the advancement of human activities. The low relief plains of Potkozarje cover the contact zone between the Kozara Mountain lower slopes on one side and Lijevce Polje plain, Prijedorsko Polje plain and alluvial plains of the Una, Vrbas, Sava and Sana rivers on the other side.

From morphostructural and functional points of view, Potkozarje is linked to the area of the Kozara Mountain, making the whole region suitable for specific types of mountain tourism. Morphophysiognomy of the hills and foothills, their geological formation and climate conditions determine the hydrographic properties of the region. More recently, the anthropogenic activities have had a considerable impact.

Potkozarje incorporates an elaborate hydrographic network with surface watercourses (rivers, brooks and creeks) being the most dominant features. Other hydrographic forms are groundwater and regular and thermal springs.

Microclimatic characteristics are rather specific and the precipitation plays a pertinent role in the regime of both surface water and groundwater.

The major hydrological characteristics of Potkozarje are the rivers of Una, Sava, Vrbas and Sana with their tributaries. The opportunities to valorize these rivers are many, particularly in the fields of agriculture and tourism. Still, there are certain limitations, such as floods resulting from the precipitation regime, high water level, asynchronous water flow, unattended river beds, etc.

The aim of the paper is twofold. Firstly, to assess the hydrographic potentials of Potkozarje. Secondly, to define a model of sustainable development within which different processes regarding ecological sustainability and water use in agriculture and tourism occur.

The paper analyzes the natural complex of the region, focusing on hydrographic and hydrogeological features. Taking into account the defined hydrographic characteristics, we assess the use of mineral water, surface water and groundwater, focusing on the development of spa tourism and water supply networks. Finally, the hydrotechnical 
solutions for the regulation of water regime and protection of agrarian soil are being accounted for.

Keywords: region, Potkozarje, surface water, groundwater, protection from water.

\section{INTRODUCTION}

The Kozara Mountain system and its corresponding area of Potkozarje are located at the rim of Pannonian Basin as a part of the flysch formation ranging from Petrova Gora and Zrinska Gora in the Republic of Croatia to the Cer and Vlasic mountains in West Serbia. This mountain system and its wider region represent a merging area between the Pannonian Basin in the north, and the mountain and lowland area in the south.

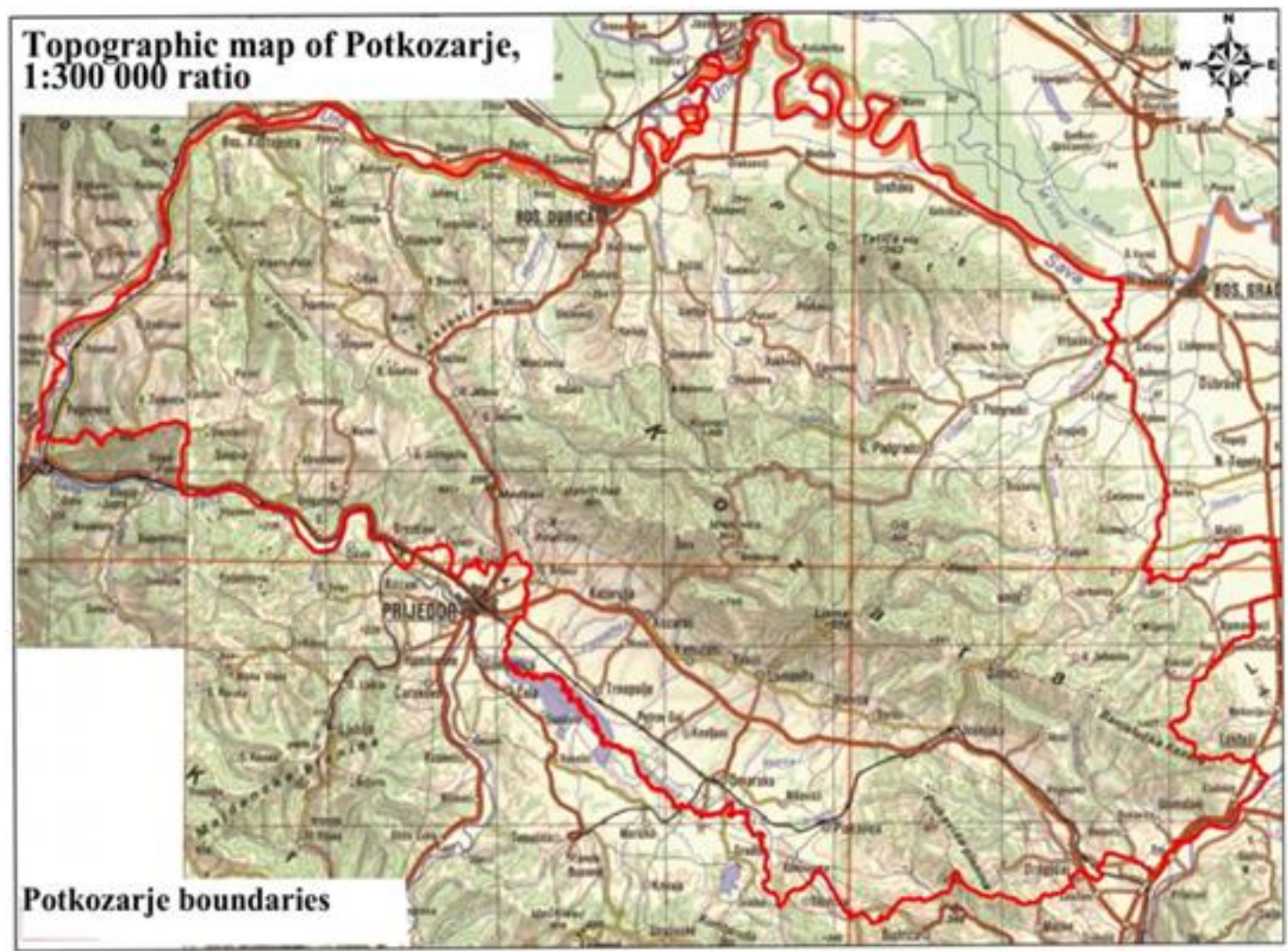

Figure 1. Topographic map of Potkozarje, 1:300 000 ratio [1

Dubica Plain in the north-west and slopes of Veliko Pastirevo and Malo Pastirevo in the west of Potkozarje touch the right bank of the Una River, which represents the boundary line with the Republic of Croatia. The northern slopes of the Prosara Mountain touch the Sava and Una river banks. In the north-east, there is a line of demarcation between Potkozarje and Lijevce Polje plain (120 m altitude), along the rivers of Jablanica, Vrbaska and Ljubinja, which run through an alluvial plain flooded by currents from the Kozara and Prosara mountains. The eastern and south-eastern slopes of the mountain system (Banjalucka Kozara and Piskavica mountains) reach the left bank of the Vrbas River. The southern boundaries of the area are rims of Prijedorsko Polje plain and the Sava River alluvial plain. 
High hills and their contact zones with lowlands of Lijevce Polje plain, Prijedorsko Polje plain, Dubica Plain and alluvial plains of the Una, Vrbas, Sava and Sana rivers represent the basic morphostructural and functional characteristics of Potkozarje.

The hilly terrain, rich in both intermittent and perennial water streams, is the contact area between lowlands and highlands. The usability of the agrarian soil is limited due to water streams flowing down from the hills, resulting in erosion.

Taking into account the geological and tectonic framework of the Kozara Mountain and Potkozarje region, there are substantial deposits of minerals, metals, non-metals and caustobioliths. The complex geological composition (including tectonics, stratigraphy and lithology) resulted in a complex hydrological network and the occurrence of water streams with different physical and chemical (thermal and mineral) properties, especially in the north of the region (Ljesljani and Mljecanica) [8].

It is the pedological characteristics that are directly connected with other elements of the environment. Large zones covered in alluvial plains and different types of soil in hilly areas, resulting from different pedogenic factors, are pertinent from the agrarian point of view. Generally, various types of soil and specific climate conditions are beneficial for distinctive biogeographical communities and natural ecosystems, including cultivation of specific plants and performance of unique human activities.

\section{SURFACE WATER AND GROUNDWATER AS COMPONENTS OF REGIONAL DEVELOPMENT}

The hydrographic network of Potkozarje is a result of the hydrogeological relief evolution and it represents some of the basic functional characteristics of the region.

In line with the hydrogeological properties, the rock mass of the Potkozarje region is classified into three categories: highly permeable, permeable, and impermeable. [2].

Highly permeable rocks are located at the contact zone between the lower slopes of the Kozara Mountain and the rim parts of Lijevce Polje plain. This category of rock includes limestone deposits, carstified dolomites, dolomitic limestone, gravel and sand.

Hydrological diversity of the Potkozarje region is associated with the hydrogeological composition and hypsometric position of the rock mass. The groundwater circulates through permeable rocks characterized with intergranular porosity and high permeability. This category of rocks may be found in the Prijedor Basin, Dubica alluvial plain, parts of the Una Basin, the area between the towns of Novi Grad and Kozarska Dubica, and next to the Sava River bank.

Highly permeable rocks originate from the Miocene and Pliocene epochs. The following types of rocks belong to this category: argillaceous limestone, dolomitic limestone and limestone with random hornstone occurrence. The rock formations share specific hydrogeological properties as they stretch along several long and narrow zones: KnezicaPucari, Dragelji-Jurkovica and Puharska-Kozarac.

The rock formations originating from the Pliocene epoch are located at the contact zone between the north-eastern slopes of the Kozara Mountain and Lijevce Polje plain (next to Jablanica) and at the contact zone between lower southern slopes of the Kozara Mountain and Prijedor Basin.

„It is in these rocks that random aquifers occur. The discharge takes place at springs with the flow rate of $10 \mathrm{l} / \mathrm{s}$ and rarely higher. Springs are typically located in either erosive areas or at the contact point with impermeable rocks"[3].

Highly permeable rocks are commonly typified by an elaborate groundwater circulation, with intergranular and fissure porosity, the permeability of which varies from high to 
none. These hydrological properties are usually found in the contact zone between lower slopes and higher plain rims, affecting the valorization and agrarian function.

It is the impermeable rocks that play the most pertinent role in the hydrology of the Potkozarje region. These rocks include Jurassic and Cretaceous sediments (feldspar, serpentinite, peridotite, limestone, etc.), Eocene flysch and Neogene clastic sediments located at several elongated zones: the Prosara Mountain, the Banjalucka Kozara, and west Potkozarje area (Ljesljani - Devetaci - Donja Dragotina) [2].

The Kozara Mountain ridge (Jelavac - Kozarski Kamen- Mostanica) represents a hydrogeological barrier. North and south-east from the ridge, there are branches of two discontinuous zones of banked and massive limestone, where many perennial springs are formed.

„The flow rate of the springs located in these rock masses is poor. The springs are commonly shallow and gravitation-dependent. They are located at the contact points between decomposed rocks and lower impermeable layers. Many of these springs are drained in the summer season" [3].

The mountain ridge represents a watershed of the Una, Sava and Sana river basins [7].

The alluvial plains of the Sana River, the water stream of Jablanica, the springs in Matarusko Polje plain (north-east of the region) and Medjedja (north-west of the region) are valuable for the exploitation of groundwater accumulations, which might provide local settlements with water and irrigate the agrarian soil.

Alluvial sediments of the Sana River (gravel) are actually highly permeable rocks [9] [10]. There is a dense network of aquifers of different water levels. Basically, gravel has far better accumulation properties than carstified carbonates of the Middle Triassic epoch. Nevertheless, the thickness of gravel (3-7 m) reduces the importance of the Sana River alluvial sediments [3].

The recharge of the alluvial aquifers is mainly possible due to the Sana River infiltration and the precipitation within the Kozara Mountain system. Parameters of average discharge speed (the mean value being $\mathrm{k}=2.90 \times 104 \mathrm{~m} / \mathrm{s}$ ) were obtained in the alluvial gravel deposits. The alluvial plain of the Sana River, downstream towards Novi Grad, is characterized by alluvial sediments separated with limestone by a thick clay layer [3] [10].

Hydrogeological properties in the south of the region are complex because the Quarter sediments partly lean directly against limestone. As a consequence, many aquifers are formed within limestone with karst and fissure porosity.

Such hydrogeological properties cause shallow aquifers and frequent floods, which reduce an opportunity to manage and use agricultural soil in the south Potkozarje region. There are many fissure aquifers in the Miocene limestone in the west Potkozarje region, south from Kostajnica (Mrakodol area). Six springs are being abstracted for the purpose of providing the municipality of Kostajnica with water supplies. Their minimum flow rate is rarely higher than $3 \mathrm{l} / \mathrm{s}$ [3].

In the north Potkozarje region, at the mouth of the Una River into the Sava, there is a groundwater accumulation in the gravel layers of the two water streams. The greatest abstraction of water is performed in Medjedja (the municipality of Kozarska Dubica). In the gravel sediments of the Sava River, there is a dense network of aquifers. The groundwater abstracted from the Medjedja area is used for supplying the north-west Potkozarje region. The average water abstraction rate (three active springs) from Medjedja is $951 / \mathrm{s}$ [3]. Aquifer formed in gravel sediments in the contact zone between lower north-eastern slopes of the Kozara and Lijevce Polje plain are under the impact of 
the lower Jablanica water stream. The gravel located in the upper stream contains some fractions characterized by bigger grains and sand. In the north-east Potkozarje region, water supplies are provided by the water abstraction from the Zeravica area. The agricultural soil is irrigated by water from the Jablanica and Jurkovica rivers and by aquifers drained from the Kozara slopes. The complex stratigraphic composition and tectonic relations in west Potkozarje (Ljesljani near Novi Grad) cause diverse hydrogeological properties and rock mass functions, which further results in spillage of mineral and thermal water. The thermal water in Ljesljani is famous for its hyperalkalinity ( $\mathrm{pH}$ 11.7). At this location, a detailed hydrogeological mapping in 1980s registered twelve springs (a typical flow rate being $0.1 \mathrm{l} / \mathrm{s}$ and rarely up to $0.5 \mathrm{l} / \mathrm{s}$ ) -11 mineral water springs $(952-2758 \mathrm{mg} / \mathrm{l})$ and only one thermal water spring (Slatina Ljesljani location, the water temperature being $20^{\circ} \mathrm{C}$ ). The idea was to drill a bore hole at the location of the thermal spring near a modern Ljesljani spa center (currently in construction). The bore hole covered a large amount of water, the temperature being $30^{\circ} \mathrm{C}$. The flow rate at the bore hole was (and still is) 7 1/s. In addition, there are indications of oil and gas deposits in deeper layers [3], which make this location appropriate for further hydrogeological research. Mineral springs in the region are commonly located in west Potkozarje (Ljesljani) and north-west Potkozarje (Mljecanica). Nowadays, the mineral water is only exploited in Mljecanica (spa tourism). The flow rate of mineral springs in Ljesljani zone is $0.1-0.5 \mathrm{l} / \mathrm{s}$, rarely up to $1.0 \mathrm{l} / \mathrm{s}$. Mineral springs are located in the villages of Svodna, Prusci, Strigova, Jelovac, Hajderovci and Mljecanica. The only valorized spring is the one in Mljecanica, where the mineral water is pumped through a well for the purpose of the spa [3].

The mineral water in Mljecanica is exploited through several minor springs formed along the Mljecanica River at two separate sites. The bore hole is $80 \mathrm{~m}$ deep but an attempt to drill a bore hole in older sediments in order to reach water of higher temperature failed. What is interesting is the fact that drilling deeper than 80 meters resulted in reaching a mixture of mineral and fresh atmospheric water. The reservoir water balance is $10 \mathrm{l} / \mathrm{s}$, and the potential reservoir is $30 \mathrm{l} / \mathrm{s}$. The water temperature is $14.7^{\circ} \mathrm{C}$ and the degree of mineralization is $2.900 \mathrm{mg} / \mathrm{l}$. The following categories were singled out by the calculation of water reservoirs in Mljecanica in 2004: category A (2.00 1/s), category B (5.00 1/s), category C1 (10.00 l/s), and category C2 (30.00 l/s) [3].

Taking into consideration hydrographic properties of the Potkozarje region, there is a potential for the mineral water exploitation for the purpose of spa tourism as well as fresh water exploitation for water supplies. 


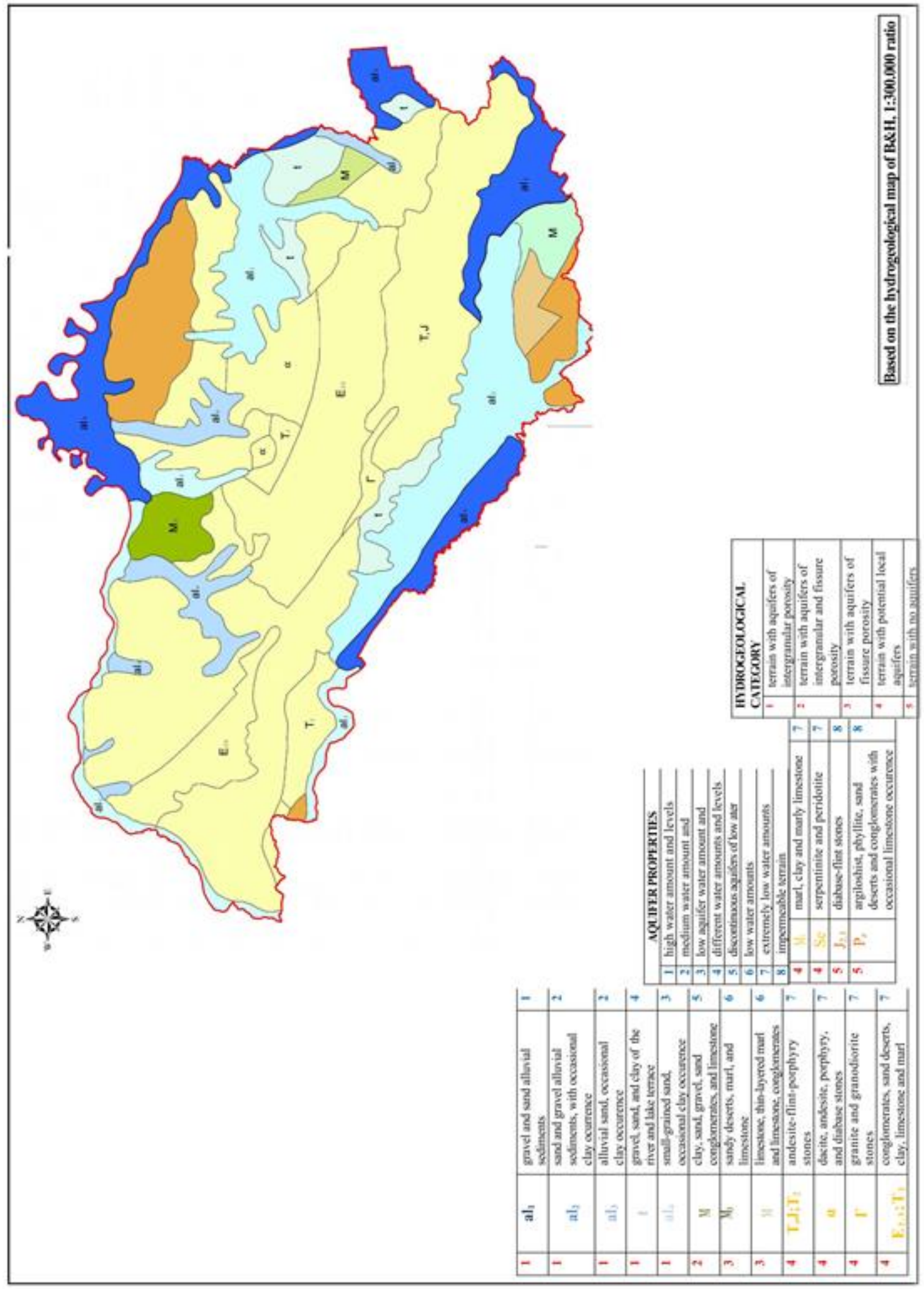

Figure 2. Hydrogeological map of Potkozarje, 1:300 000 ratio. 


\section{PROTECTION OF AGRICULTURAL SOIL FROM SURFACE WATER AND GROUNDWATER}

There are hydrotechnical solutions for the protection and exploitation of agrarian soil taking into account the morphophysiognomic composition of the region. The solutions involve the valorization of the contact zone between the lower Kozara slopes and the alluvial plain rim with an aim to protect the agrarian soil from surface water and groundwater. [6].

The drainage of surplus groundwater is conducted through the drainage systems in Posavina-Novi Grad, Dubica Plain, Liman-Cerovljani, Dolina and Bajinci areas.

There are high embankments in Dubica Plain protecting the soils from high waters of the Una and Sava rivers and a dyke constructed in the south to protect the soil from waters in the foot of the Kozara Mountain.

„In the Dubica Plain area, there are pumps and dykes, which drain the surplus water into the recipient streams and protect the soil from groundwater. Generally, the protection from surface water and groundwater is unsatisfactory. The position of the defensive constructions is not high enough and there are plans for their reconstruction. The dykes are not maintained properly and their permeability is decreasing, which negatively affects the whole system." [4].

For the purpose of flood control, there are embankments $8 \mathrm{~km}$ long along the right Una River bank and $19.5 \mathrm{~km}$ long along the right Sava River bank. The embankments were built during the period 1956-1960 in line with the existing criteria. There is a plan for the reconstruction of the embankments, which would ensure the $1.0 \mathrm{~m}$ cant in cases of maximum water level. A part of the reconstruction is already completed in the Donja Gradina memorial zone covering the length of around $3.100 \mathrm{~m}$. In addition, a master project for the reconstruction has been designed. Some sections of the embankment zone are still being flooded [4].

„The protection from mountain water in the south of Dubica Plain is provided by a dyke $7.500 \mathrm{~m}$ long from the mouth of the Mostanica River into the Una all the way to the Rakovica River and a dyke $12.250 \mathrm{~m}$ long from the Rakovica River to the village of Orahova. The upper dyke flows into the Una River and the lower dyke flows into the Sava River. There have been occasional overflows of water in both dykes" [4].

The drainage of surplus groundwater in west Potkozarje (Posavina-Novi Grad) is performed through a pump station constructed in 1956 (the capacity being 5,5 m3/s) and a pump station constructed in 1986 (the capacity being 4 1/s). The main drainage network covers the surface of 1.400 ha [4].

The drainage of surplus groundwater in north-east Potkozarje (Liman-Cerovljani) is performed through the Liman pump station, whereas the southern parts are drained through Jurkovica-Jablanica and Topola-Jablanica dykes. The drainage system is satisfactory. Beside the main and secondary dyke system, there is an incomplete pipe drainage system.

The drainage of surplus groundwater in this area is performed through Dolina and Bajinci pump stations. The drainage system is inadequately maintained so the drainage takes place via natural drains. 


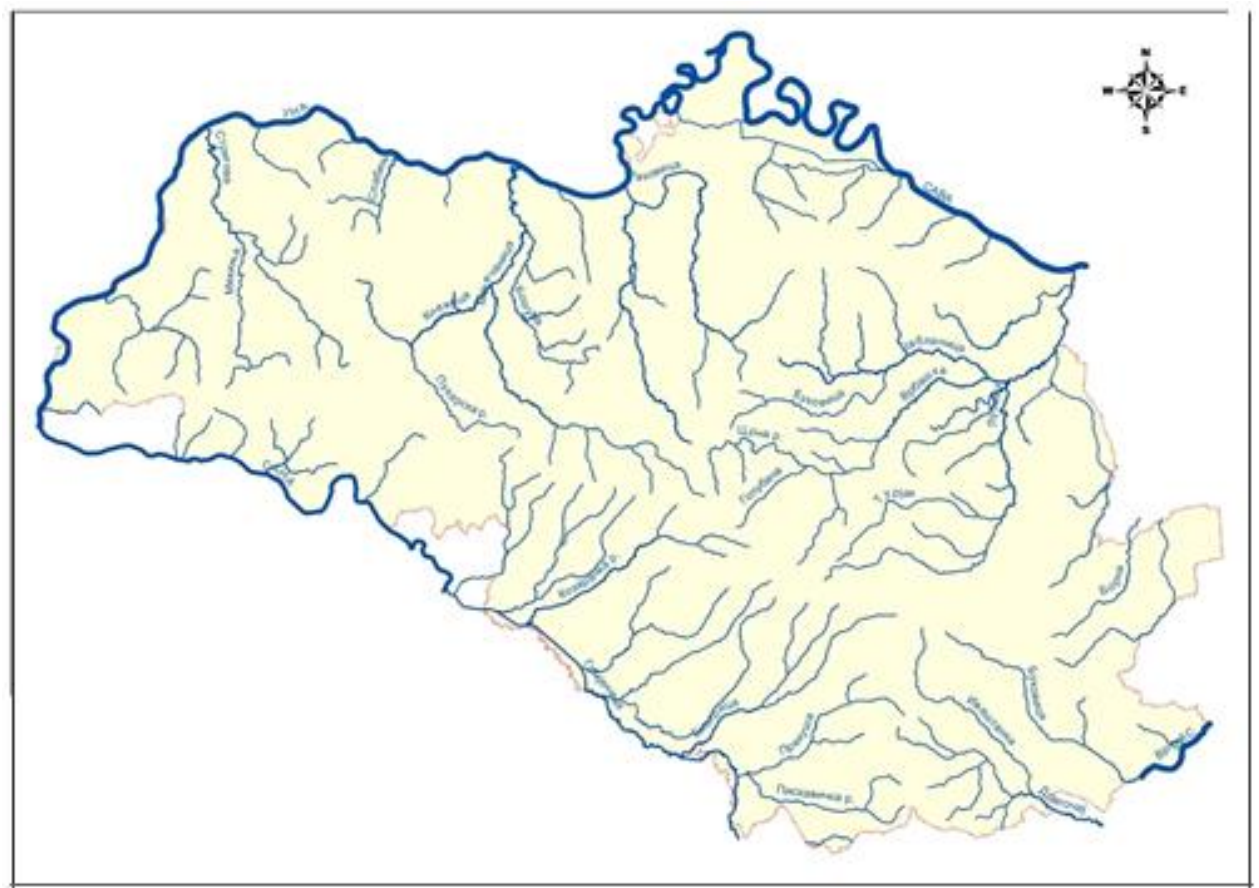

Figure 3. Hydrographic network of Potkozarje.

In line with the current state of the agrarian soil protection system, the drainage system is incomplete and unable to provide adequate protection.

„Provisionally, around $50 \%$ of the area is not covered by the drainage system, which demands an urgent reconstruction and upgrade" [4].

Given the hydrotechnical management and usage of the agrarian soil, we should point out agrarian areas with detailed drainage systems [6]. There is an elaborate drainage system constructed in Dubica Plain (the settlements of Klekovci, Medjedja, Crnac and Poljice) and in south Potkozarje region in the contact zone between lower mountain slopes and Prijedor Basin (the settlements of Bistrica, Omarska, Orlovci and Kamicani). The drainage system in Dubica Plain covers 820 ha and in south Potkozarje it covers 370 ha. Drainage systems in the region tend to be inadequately maintained and the assessment of their capacities and functioning should be prioritized.

Regarding hydromelioration system in the Potkozarje region, Dubica Plain and valleys of the Una and Sava rivers should be included [4].

Hydrotechnical systems require reassessment in order to provide the proper soil irrigation in the entire region.

Speaking of the minimum stream flow in the summer season when the irrigation is most essential, the water streams of Potkozarje cannot provide the sufficient amount of water unless new regulation systems are constructed (the exceptions being the rivers of Una, Sana and Vrbas) [5] [7].

\section{CONCLUSION}

The hydrogeological composition and hypsometric position of the rock mass resulted in the hydrological diversity of the Potkozarje region. The groundwater circulates through permeable rocks of intergranular porosity, which have pronounced permeability properties. These rock masses are located in Prijedor Basin, Dubica alluvial plain, parts of the Una Basin (from Novi Grad to Kozarska Dubica) and along the Sava River bank. 
Groundwater circulation is evident in areas of highly permeable rocks with intergranular and fissure porosity, where permeability varies from relatively low to high. Such hydrological features are typical in the contact zone between lower Kozara slopes and rim parts of Lijevce Polje plain, Prijedorsko Polje plain, and Dubica Plain. It is in these locations that hydrological properties affect the valorization and the development of agriculture.

The alluvial Sava Plain in south Potkozarje, Jablanica water stream, and fissure aquifers in Matarusko polje (north-east Potkozarje) and Medjedja (north-west Potkozarje) are of an utmost pertinence for the hydrotechnical solutions which might help exploit groundwater for the purpose of water supplies and irrigation of the agrarian soil.

Hydrogeological features of south Potkozarje are very complex because the Quarter sediments partly lean directly against limestone. As a consequence, many aquifers are formed within limestone with karst and fissure porosity. The results are shallow aquifers and frequent floods, which limit the valorization of agricultural soil.

Aquifers formed in gravel sediments in the contact zone between lower north-eastern slopes of Kozara and Lijevce Polje plain are highly affected by lower Jablanica water stream. The agricultural soil is irrigated by water from the Jablanica and Jurkovica rivers as well as by aquifers drained from the Kozara slopes.

The complex geological composition in west and north-west Potkozarje (Ljesljani near Novi Grad and Mljecanica near Kozarska Dubica) resulted in diverse hydrogeological features and rock mass, which further enabled the occurrence of mineral and thermal water.

Besides, there are indications of oil and gas deposits in deeper layers in Ljesljani, which makes the location pertinent for further hydrogeological studies.

Given the hydrographical properties of the region, there is a potential for thermal mineral water exploitation, especially for the purpose of spa and medical tourism.

In line with the current state of the agrarian soil protection system, the drainage system in the contact zone between lower Kozara slopes and rim parts of Lijevce Polje plain, Prijedorsko Polje plain and Dubica Plain is incomplete and unable to provide adequate protection. The drainage systems are generally poorly maintained and the assessment of their functioning should be a priority. Regarding hydromelioration system in the Potkozarje region, the agricultural soil in Dubica Plain and valleys of the Una and Sava rivers should be included.

\section{REFERENCES}

[1] Војногеографски институт, Топографска карта $1: 300$ 000, Београд, 1976, лист Бања Лука

[2] Хидрогеолошка карта СФРЈ, листови Дубровник 1:300 000, Сарајево 1:300 000, Загреб 1:300 000, Геолошки завод, Зворник

[3] Минералне сировине Републике Српске, Монографија, Републички завод за геолошка истраживања РС „Геозавод” Зворник, 2011. стр .436-420; стр. 439-449;

[4] Основа заштите, коришћења и уређења пољопривредног земљишта Републике Српске као компоненте процеса планирања коришћења земљишта, Пољопривредни институт Републике Српске, Завод за агрохемију и агроекологију Бањалука, Влада Републике Српске, Министарство пољопривреде, шумарства и водопривреде, Бањалука, 2009. стр. 4854 
[5] Оквирни план развоја водопривреде Републике Српске, Републичка дирекција за воде Бијељина, Влада Републике Српске, Министарство пољопривреде, шумарства и водопривреде, Бијељина, 2006. стр. 95-96

[6] T. Mišlicki Tomić, В. Spasojevic, Неки проблеми развоја аграра у Поткозарју, ГЛАСНИК/HERALD, Vol. XVIII, No. 18, pp. 105-129, 2014.

[7] B. Рајчевић, T. Mišlicki Tomić, Č. Crnogorac, UPPER STREAM OF THE RIVER SANA JUSTIFICATION OF BUILDING HYDRO POWER PLANTS WITH RESPECTIVE ACCUMULATIONS, Proceedings ISSN 1857-7636, pp. 117-126, 2020.

[8] T. Mišlicki Tomić, В. Чолић, Mineralni resursi kao faktor regionalnog razvoja zapadnog Potkozarja, Зборник радова, pp. 349-356, 2013.

[9] Spahic, M, Temimovic, E, Jahic, H., HYDROGEOLOGICAL CATEGORISATION OF THE SANA RIVER, Acta geographica Croatica, Volumen 39, Zagreb, 2012, pp 65-75

[10] Vujacic, M, Crnogorac, C., Engineering-geological characteristics of the upper stream of the Sana River as foundation for designing hydro power plants with respective accumulations (The Lekici hydro power plant, the Slatina hydro power plant), research paper, Banja Luka, 2004. 